7. Бобринский А.А. Гончарная технология как Центрального и Северного Казахстана. Караганда: объект историко-культурного изучения // Актуальные проблемы изучения древнего гончарства (коллективная монография). Самара, 1999. С. 31-32.

8. Зданович Г.Б. Основные характеристики петровских комплексов Урало-Казахстанских степей (к вопросу о выделении петровской культуры) // Бронзовый век степной полосы Урало-Иртышского междуречья. Челябинск: Башк. ун-т, 1983. С. 48-68.

9. Ткачев А.А. Периодизация и хронология алакульских памятников Центрального Казахстана // Вопросы периодизации археологических памятников

Kap. ун-т, 1987. С. 25-35.

10. Ткачев А.А. Особенности нуртайских комплексов Центрального Казахстана // Вестник археологии, антропологии и этнографии. Вып. 2. Тюмень, 1999. C. $22-29$.

Статья публикуется при поддержке гранта: ИРН АР05132375 «Исследование многокомпонентной системы жизнеобеспечения древних коллективов по материалам поселений Центрального Казахстана».

\title{
CULTURAL ATTRIBUTION OF THE DWELLING-WORKSHOP ON THE BASIS OF THE TALDYSAY SETTLEMENT CERAMICS ANALYSIS
}

(C) 2018

\author{
Yermolayeva Antonina Sergeevna, leading researcher of Prehistoric Archeology Department \\ Kaliyeva Zhanargul Serikovna, researcher of Prehistoric Archeology Department \\ Dubyagina Ekaterina Viktorovna, junior researcher of Prehistoric Archeology Department \\ A.Kh. Margulan Institute of Archaeology (Almaty, Republic of Kazakhstan)
}

\begin{abstract}
The following paper considers important characteristics of classical ceramic collection from the dwelling-workshop situated in the metallurgical settlement Taldysay. The workshop had one period of settlement and belongs to the Petrov archeological culture (the type of the monument is Nurtai for Central Kazakhstan). In previous years of the research, we made attempts to determine the cultural affiliation of the thermal engineering structures on the basis of ceramic material that constitutes ground and mine types in dwelling and production complexes that functioned in different chronological periods and contained various cultural materials. Due to the fact that the collection is quite limited, the present publication consists of the preliminary analysis of the artifacts and includes systematization of the accumulated ceramic materials from the settlement. From 100 fragments, only 41 specimens were selected for the further analysis, and 35 of which were found directly in the heat engineering facilities and near them. Importantly, even now we can conclude that the ceramic material proves that the thermal engineering structures of ground and mines types in a single-layer dwelling-workshop belong to the monuments of Petrov archeological culture of Nurtai type. Finally, the considered collection determines the start of the metal production on the territory of Central Kazakhstan by the first half of the second millennium BC.

Keywords: Zhezkazgan-Ulytay Region; bronze age; metal production; settlement; dwelling-workshop; heat engineering facilities; mine type pit-furnace; fragments; ceramics; potted jar; sharp-edged vessel; double-blade plate knife; second millennium BC; Petrov's culture; Nurtai type.
\end{abstract}

УДК 902/904, 902.6

Статья поступила в редакцию 07.06.2018

\section{НОВЫЕ ПОДХОДЫ К МОДЕЛЯМ ГЕНДЕРНЫХ РОЛЕЙ ПОЗДНЕГО БРОНЗОВОГО ВЕКА ЮЖНОГО ПРИУРАЛЬЯ: КАЗБУРУНОВСКИЙ АРХЕОЛОГИЧЕСКИЙ МИКРОРАЙОН ПО РЕЗУЛЬТАТАМ БИОАРХЕОЛОГИЧЕСКОГО АНАЛИЗА}

(C) 2018

Щербаков Николай Борисович, кандидат исторических наук, научный сотрудник лаборатории методологии и методов гуманитарных исследований

Шутелева Ия Александровна, кандидат исторических наук, научный сотрудник лаборатории методологии и методов гуманитарных исследований

Леонова Татьяна Алексеевна, кандидат исторических наук,

заведующий лабораторией методологии и методов гуманитарных исследований

Башкирский государственный педагогический университет им. М. Акмулль (г. Уфа, Российская Федераџия)

Горшков Константин Александрович, криминалист-эксперт медико-криминалистического отделения Бюро судебно-медицинской экспертизы (2. Уфа, Российская Федерация)

Гольева Александра Амуриевна, доктор географических наук, ведущий научный сотрудник отдела географии и эволюции почв

Институт географии РАН (г. Москва, Российская Федераичия)

Батурина Александра Николаевна, студент института истории и государственного управления Башкирский государственный университет (г. Уфа, Российская Федерация)

Аннотаџия. Комплексные археологические исследования, проведенные на памятниках развитого, классического позднего бронзового века на территории Южного Приуралья, Казбуруновского археологического микрорайона, позволили применить метод остеобиографии к реконструкции гендерных особенностей погребального обряда. Полученные радиоуглеродные даты позволили не только удревнить историю проживания 
на указанной территории носителей срубной и алакульской культурных традиций на 350-400 лет, но и показать нахождение всех исследуемых погребенных в одном хронологическом горизонте. Сравнительный радиоуглеродный анализ материалов погребальных и поселенческих комплексов также показал их одновременность. Данные палеоДНК дали возможность выделить особенность погребального обряда - сильную степень скорченности как гендерную характеристику погребенных. Скорченность предлагается исследовать как в «традиционном» описании - скорченность в тазобедренном суставе и скорченность в коленном суставе, так и использовать параметр скорченности в локтевом суставе погребенного. Применение антропологических анализов характеризовало ряд палеоболезней как гендерный атрибут при однородной палеодиете древнего населения Казбуруновского археологического микрорайона. Использование почвенных методов исследования позволило определить характер взаимодействия древнего населения и современной ему палеосреды, выявляя таким образом уровень древнего антропогенного воздействия на окружающую среду, выявить вероятные традиции в строительстве древнего населения.

Ключевые слова: развитый классический поздний бронзовый век Южного Приуралья; срубная и алакульская археологические общности; остеобиография; изотопные анализы (d13C и $\mathrm{d} 15 \mathrm{~N})$ для реконструкции палеодиеты и установления радиоуглеродной хронологической шкалы; палеогенетический анализ; почвенные анализы; палеоантропологические анализы.

Исследование гендерных ролей в дописьменных обществах является трендом современных археологических построений, основанных на воссоздании гендерных взаимодействий, гендерной идентичности в социальной реконструкции, в том числе по археологическим данным погребальных комплексов позднего бронзового века Южного Приуралья.

В настоящее время археологические исследования позднего бронзового века вернулись к проблеме соотношения социального и персонального, заменив понятие «социальная структура» социальным взаимодействием. В исследованиях погребальных традиций позднего бронзового века можно выделить три наиболее важных составляющих: анализ погребальных данных (пространственно-временные, социально-временные изменения, константные и изменяющиеся элементы погребальных комплексов и т.д.); исследование погребальных традиций (как отражение социальной реальности); анализ теории социального действия в создании погребального обряда (погребальные практики, ландшафт, феноменология). Перечисленные факторы позволяют рассмотреть погребальную практику через призму исторического контекста и биокультурных свидетельств.

Погребальная практика становится результатом идентичности и жизненного опыта живых акторов погребального процесса, скорбящих и самих мертвых. Такой подход к пониманию погребального обряда позволяет объединить археологические построения с биологическими данными. В настоящее время наиболее перспективным является применение интегративного подхода соединения биоархеологии (в нашем случае остеобиографии) и археологии. Так, для остеобиографии кости - это предмет исследования, отражающий идентичность как результат жизненного опыта человека прошлого актора собственной остеобиографии (рис. 1). В археологии же кости скелета являются объектом исследования наряду с погребальными традициями как результата событий жизни погребенных, отражающих процесс формирования их жизненного опыта [1, p. 451-462; 2, p. 780-790].

В историографии обозначенной проблемы сложились три направления: остеоархеология в Великобритании, палеоантропология в Северной Америке, биоархеология во французской археологической теории и пограничные, находящиеся между англоамериканскими и французскими исследованиями остеоархеологии [3, p. 62-63]. Остеобиография является своеобразной «историей жизни, написанной на кости» [4]. Данное направление сложилось в начале 1970-х гг., объединив методы судебной медицины и остеологии с биоисторией. Если скелет человека считать своего рода осью между жизнью и смертью [5, p. 109-133], то остеобиографическое описание позволяет реконструировать его поведение. Современные остеобиографические исследования были дополнены результатами палеогенетических анализов.

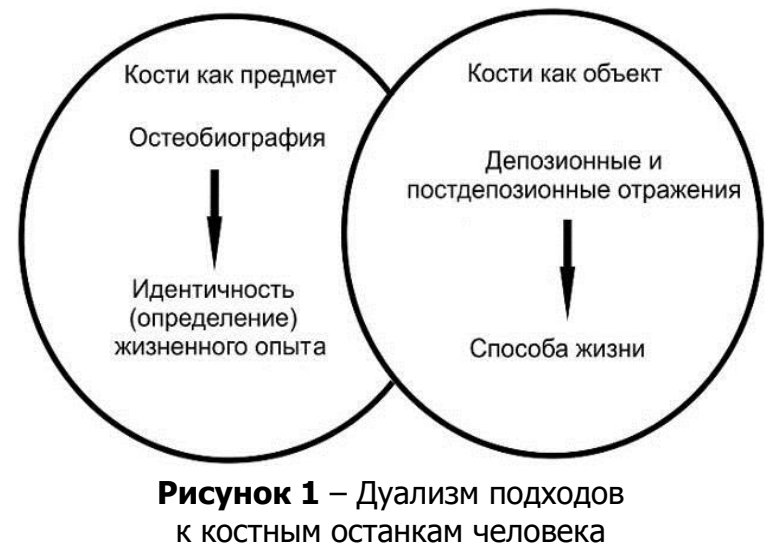

В ходе проведенных интердисциплинарных исследований территории Казбуруновского археологического микрорайона, в который входит группа из 7 поселений, 8 курганных могильников (в общей сложности 72 курганных насыпи) и 3 одиночных кургана, были получены новые данные по гендерной истории позднего бронзового века Южного Приуралья. К развитому, классическому позднему бронзовому веку Казбуруновского археологического микрорайона относится семь поселений и три частично или полностью исследованных курганных могильника. В непосредственной близости друг от друга расположены Усманово - 1, курганный могильник (Казбуруновские I курганы), Усманово - 2, курганный могильник (Казбуруновские II курганы), Усманово - 3, курганный могильник (Казбуруновские III курганы), Усманово - 4 поселение (Усмановское поселение, Усмановское I поселение), Усмановское II поселение Усмановское III поселение (Усманово - 3, поселение). Проведенные А.А. Гольевой почвенные анализы показали наличие устойчивых архитектурных традиций с использованием гипса на поселенческих памятниках, а также практически полное отсутствие погребенной почвы в погребальных памятниках, что также можно считать устойчивой архитектурной традицией $[6$, с. $50-55 ; 7$, с. $1193-$ 1194; 8, p. 67-68; 9, p. 29-36]. 
Культурно-хронологически памятники позднего бронзового века Казбуруновского микрорайона могут быть отнесены к одному периоду (табл. 1) и соотнесены с периферийной зоной как срубной, так и андроновской (алакульской) археологических культур. Сопоставление исследуемых объектов на уровне единого хронологического горизонта потребовало более строгого отношения к радиоуглеродным датам, поэтому ряд костяков был продатирован дважды в разных лабораториях. Полученная погрешность в 95-55 лет является допустимой для данного периода. Полученные результаты позволили провести гендерное сопоставление в одном хронологическом срезе (табл. 1) [10, с. 261-279; 11, с. 143]. Анализ гендерных соотношений, проведенных для территории Южного Приуралья позднего бронзового века, является новым в изучении погребальных и поселенческих памятников.

таблица 1 - Результаты радиоуглеродного анализа $\left({ }^{14} \mathrm{C}\right)$ материалов Казбуруновского археологического микрорайона

\begin{tabular}{|c|c|c|c|c|c|c|c|c|c|c|}
\hline $\begin{array}{c}\text { Памятник } \\
\text { и год исследования }\end{array}$ & $\begin{array}{l}\text { Иссле- } \\
\text { дован- } \\
\text { ный } \\
\text { обра- } \\
\text { зец } \\
\end{array}$ & $\begin{array}{l}\text { Лабо- } \\
\text { ратор- } \\
\text { ный } \\
\text { код }\end{array}$ & $\begin{array}{l}\text { Радио- } \\
\text { углерод- } \\
\text { ная дата } \\
\left({ }^{13} \mathrm{C} /{ }^{12} \mathrm{C}\right)\end{array}$ & $\begin{array}{l}\text { Соотно- } \\
\text { шение } \\
\text { (коэффи- } \\
\text { циент) } \\
{ }^{13} \mathrm{C} /{ }^{12} \mathrm{C} \\
\end{array}$ & $\begin{array}{l}\text { Радио- } \\
\text { угле- } \\
\text { родная } \\
\text { дата } \\
{ }^{14} \mathrm{C} \\
\end{array}$ & $\begin{array}{l}\text { Лабо- } \\
\text { ратор- } \\
\text { ный } \\
\text { код }\end{array}$ & $\begin{array}{c}\text { Иссле- } \\
\text { дован- } \\
\text { ный об- } \\
\text { разец }\end{array}$ & $\delta 13 \mathrm{C}$ & $\delta 15 \mathrm{~N}$ & $\begin{array}{l}\text { Возраст } \\
\text { по калиб- } \\
\text { рованной } \\
\text { дате (cal } \\
\text { ВС) } 95 \%\end{array}$ \\
\hline $\begin{array}{l}\text { Казбуруновский I } \\
\text { курганный могиль- } \\
\text { ник, 2009 г., курган } \\
\text { № 4, погребение № } 1 \\
\text { (AMS) }\end{array}$ & зуб & $\begin{array}{c}\text { Beta- } \\
347344\end{array}$ & $\begin{array}{l}3420 \pm \\
\pm 30 \mathrm{BP}\end{array}$ & $-19,7 \mathrm{o} / \mathrm{oo}$ & $\begin{array}{c}3520 \pm \\
\pm 30 \\
\text { BP }\end{array}$ & $\begin{array}{c}\text { Beta- } \\
439417\end{array}$ & $\begin{array}{c}\text { коллаген } \\
\text { костной } \\
\text { ткани }\end{array}$ & & $\begin{array}{l}11,0 \\
\text { o/oo }\end{array}$ & $\begin{array}{c}1780-1630 \\
\text { BCE }\end{array}$ \\
\hline $\begin{array}{l}\text { Казбуруновский I } \\
\text { курганный могиль- } \\
\text { ник, } 2009 \text { г., курган } \\
\text { № 4, погребение № } 1\end{array}$ & кость & $\begin{array}{c}\text { Beta- } \\
451579\end{array}$ & $\begin{array}{c}3440+/- \\
30 \mathrm{BP}\end{array}$ & $-19,3$ & & & $\begin{array}{c}\text { коллаген } \\
\text { костной } \\
\text { ткани }\end{array}$ & $-19,3$ & 10,7 & $\begin{array}{c}1875-1665 \\
\text { BCE }\end{array}$ \\
\hline $\begin{array}{l}\text { Казбуруновский I } \\
\text { курганный могиль- } \\
\text { ник, } 2014 \text { г., курган } \\
\text { № 23, погребение } \\
\text { № } 4 \text { (левое) (AMS) } \\
\end{array}$ & зуб & $\begin{array}{c}\text { Beta- } \\
395800\end{array}$ & $\begin{array}{l}3340 \pm \\
\pm 30 \mathrm{BP}\end{array}$ & $-19,7 \mathrm{o} / \mathrm{oo}$ & $\begin{array}{c}3440 \pm \\
\pm 30 \\
\text { BP }\end{array}$ & & & & & $\begin{array}{c}1690-1520 \\
\text { BCE }\end{array}$ \\
\hline $\begin{array}{l}\text { Казбуруновский I } \\
\text { курганный могиль- } \\
\text { ник, } 2014 \text { г., курган } \\
\text { № 23, погребение } \\
\text { № } 4 \text { (левое) } \\
\end{array}$ & кость & $\begin{array}{l}\mathrm{Ua}- \\
56446\end{array}$ & $\begin{array}{c}3407+/- \\
30 \mathrm{BP}\end{array}$ & $-19,4$ & & & $\begin{array}{c}\text { коллаген } \\
\text { костной } \\
\text { ткани }\end{array}$ & $-19,4$ & 12,1 & $\begin{array}{c}1745-1620 \\
\text { BCE }\end{array}$ \\
\hline $\begin{array}{l}\text { Казбуруновский I } \\
\text { курганный могиль- } \\
\text { ник, } 2014 \text { г., курган } \\
\text { № 23, погребение } \\
\text { № 5 } \\
\end{array}$ & кость & & & & & $\begin{array}{c}\text { Beta- } \\
439415\end{array}$ & $\begin{array}{c}\text { коллаген } \\
\text { костной } \\
\text { ткани }\end{array}$ & $\begin{array}{l}-19,7 \\
\text { o/oo }\end{array}$ & $\begin{array}{l}10,6 \\
\text { o/oo }\end{array}$ & \\
\hline $\begin{array}{l}\text { Казбуруновский I } \\
\text { курганный могиль- } \\
\text { ник, } 2014 \text { г., курган } \\
\text { № 23, погребение } \\
\text { № } 4 \text { (правое) } \\
\end{array}$ & кость & $\begin{array}{c}\text { Ua- } \\
56447\end{array}$ & $\begin{array}{c}3422+/- \\
30 \mathrm{BP}\end{array}$ & $-19,3$ & & & $\begin{array}{c}\text { коллаген } \\
\text { костной } \\
\text { ткани }\end{array}$ & $-19,3$ & 12,6 & $\begin{array}{c}1755-1630 \\
\text { BCE }\end{array}$ \\
\hline $\begin{array}{l}\text { Казбуруновский I } \\
\text { курганный могиль- } \\
\text { ник, } 2014 \text { г., курган } \\
\text { № 23, погребение } \\
\text { № 3 }\end{array}$ & кость & & & & & $\begin{array}{c}\text { Beta- } \\
439416\end{array}$ & $\begin{array}{c}\text { коллаген } \\
\text { костной } \\
\text { ткани }\end{array}$ & $\begin{array}{l}-19,0 \\
\text { o/oo }\end{array}$ & $\begin{array}{l}10,7 \\
\text { o/oo }\end{array}$ & \\
\hline $\begin{array}{l}\text { Казбуруновский I } \\
\text { курганный могиль- } \\
\text { ник, } 2014 \text { г., курган } \\
\text { № 23, погребение } \\
\text { № } 2 \text { (ребенок) }\end{array}$ & кость & & & & & $\begin{array}{c}\text { Beta- } \\
439414\end{array}$ & $\begin{array}{c}\text { коллаген } \\
\text { костной } \\
\text { ткани }\end{array}$ & $\begin{array}{l}-19,4 \\
\text { o/oo }\end{array}$ & $\begin{array}{l}11,2 \\
\mathrm{o} / \mathrm{oo}\end{array}$ & \\
\hline $\begin{array}{l}\text { Казбуруновский I } \\
\text { курганный могиль- } \\
\text { ник, } 2014 \text { г., курган } \\
\text { № 23, погребение } \\
\text { № } 2 \text { (ребенок) } \\
\end{array}$ & кость & $\begin{array}{c}\text { Ua- } \\
56444\end{array}$ & $\begin{array}{c}3415+/- \\
31 \mathrm{BP}\end{array}$ & $-19,3$ & & & $\begin{array}{c}\text { коллаген } \\
\text { костной } \\
\text { ткани }\end{array}$ & $-19,3$ & 12,6 & $\begin{array}{c}1750-1620 \\
\text { BCE }\end{array}$ \\
\hline $\begin{array}{l}\text { Казбуруновский I } \\
\text { курганный могиль- } \\
\text { ник, } 2009 \text { г., курган } \\
\text { № 4, погребение № } 2\end{array}$ & кость & $\begin{array}{c}\text { Beta- } \\
451578\end{array}$ & $\begin{array}{c}3360+/- \\
30 \mathrm{BP}\end{array}$ & $-19,3$ & & & $\begin{array}{c}\text { коллаген } \\
\text { костной } \\
\text { ткани }\end{array}$ & $-19,3$ & 10,8 & $\begin{array}{c}1735-1565 \\
\text { BCE }\end{array}$ \\
\hline
\end{tabular}


Щербаков Н.Б., Шутелева И.А., Леонова Т.А., Горшков К.А. и др.

Новые подходы к моделям гендерных ролей позднего бронзового века..

07.00.00 - исторические науки и археология

\begin{tabular}{|c|c|c|c|c|c|c|c|c|c|}
\hline (ребенок) & & & & & & & & & \\
\hline $\begin{array}{l}\text { Казбуруновский I } \\
\text { курганный могиль- } \\
\text { ник, } 2004 \text { г., курган } \\
\text { № 5, погребение № } 1\end{array}$ & кость & $\begin{array}{c}\text { Beta- } \\
451577\end{array}$ & $\begin{array}{c}3410+/- \\
30 \mathrm{BP}\end{array}$ & $-19,6$ & & $\begin{array}{c}\text { коллаген } \\
\text { костной } \\
\text { ткани }\end{array}$ & $-19,6$ & 10,7 & $\begin{array}{c}1765-1630 \\
\text { BCE }\end{array}$ \\
\hline $\begin{array}{l}\text { Казбуруновский I } \\
\text { курганный могиль- } \\
\text { ник, } 2014 \text { г., курган } \\
\text { № 23, погребение } \\
\text { № } 3\end{array}$ & кость & $\begin{array}{l}\text { Ua- } \\
56445\end{array}$ & $\begin{array}{c}3459+1- \\
30 \mathrm{BP}\end{array}$ & $-19,2$ & & $\begin{array}{c}\text { коллаген } \\
\text { костной } \\
\text { ткани }\end{array}$ & $-19,2$ & 12,2 & $\begin{array}{c}1880-1690 \\
\text { BCE }\end{array}$ \\
\hline $\begin{array}{l}\text { Казбуруновский I } \\
\text { курганный могиль- } \\
\text { ник, } 2014 \text { г., курган } \\
\text { № 23, погребение } \\
\text { № } 5\end{array}$ & кость & $\begin{array}{c}\text { Ua- } \\
56448\end{array}$ & $\begin{array}{c}3479+1- \\
30 \mathrm{BP}\end{array}$ & $-19,4$ & & $\begin{array}{c}\text { коллаген } \\
\text { костной } \\
\text { ткани }\end{array}$ & $-19,4$ & 11,9 & $\begin{array}{c}1880-1690 \\
\text { BCE }\end{array}$ \\
\hline $\begin{array}{l}\text { Казбуруновский I } \\
\text { курганный могиль- } \\
\text { ник, } 2014 \text { г., курган } \\
\text { № 23, погребение } \\
\text { № 6 }\end{array}$ & кость & $\begin{array}{c}\text { Ua- } \\
56449\end{array}$ & $\begin{array}{c}3401+/- \\
29 \mathrm{BP}\end{array}$ & $-19,7$ & & $\begin{array}{c}\text { коллаген } \\
\text { костной } \\
\text { ткани }\end{array}$ & $-19,7$ & 12,5 & $\begin{array}{c}1745-1620 \\
\text { BCE }\end{array}$ \\
\hline $\begin{array}{l}\text { Усманово - III посе- } \\
\text { ление, } 2013 \text { г. }\end{array}$ & $\begin{array}{c}\text { кера- } \\
\text { мика } \\
\text { (круп- } \\
\text { нозер- } \\
\text { нистая } \\
\text { орга- } \\
\text { ника) }\end{array}$ & $\begin{array}{c}\text { Beta- } \\
352489\end{array}$ & $\begin{array}{l}4130 \pm \\
\pm 30 \mathrm{BP}\end{array}$ & $-30,7 \mathrm{o} / \mathrm{oo}$ & $\begin{array}{l}4040 \pm \\
\pm 30 \\
\mathrm{BP}\end{array}$ & & & & \\
\hline
\end{tabular}

Проведенные остеобиографические и палеогенетические исследования позволили выделить возможные признаки гендерных ролей населения позднего бронзового века Казбуруновского археологического микрорайона (табл. 2).

Исследования выявили наличие общих системных заболеваний населения позднего бронзового века Казбуруновского археологического микрорайона, которые не зависели от гендерной принадлежности. Вероятно, что данные системные заболевания были следствием палеоландшафта, на который достаточно активно воздействовало древнее население региона. Прежде всего, это использование гипсов и карбонатов, которыми богаты местные почвы [12, p. 29-36]. Данный факт нашел отражение в накоплении избыточного кальция в костном скелете, появлении остеофитов и даже в возможном полном сращении позвонков у взрослых погребенных. Найденные костяки мужского пола имели полученные при жизни травмы костей.

Таблица 2 - Определение пола и гаплогрупп палеоДНК

\begin{tabular}{|c|c|c|c|}
\hline Место происхождения материала & $\begin{array}{l}\text { Биологический } \\
\text { пол } \\
\end{array}$ & $\begin{array}{c}\text { Гаплогруппа по } \\
\text { митохондриальной ДНК }\end{array}$ & $\begin{array}{c}\text { Гаплогруппа } \\
\text { по Y ДНК }\end{array}$ \\
\hline $\begin{array}{l}\text { Казбуруновский I курганный могильник, } 2009 \text { г., } \\
\text { Курган № 16, погребение № 2, подросток }\end{array}$ & XX (женский) & U4b1a1a1 & - \\
\hline $\begin{array}{l}\text { Казбуруновский І курганный могильник, } 2009 \text { г., } \\
\text { Курган № 16, погребение № } 1\end{array}$ & XY (мужской) & $\mathrm{J} 1 \mathrm{c} 3 \mathrm{a}$ & R1a1a1 \\
\hline $\begin{array}{l}\text { Казбуруновский I курганный могильник, } 2004 \text { г., } \\
\text { Курган № 5, погребение № } 1\end{array}$ & XY (мужской) & $\mathrm{H}$ & R1a1a1 \\
\hline $\begin{array}{l}\text { Казбуруновский I курганный могильник, } 2014 \text { г., } \\
\text { Курган № 23, погребение № 2, подросток }\end{array}$ & XX (женский) & $\mathrm{U} 5 \mathrm{~b} 2 \mathrm{a} 2$ & - \\
\hline $\begin{array}{l}\text { Казбуруновский I курганный могильник, } 2014 \text { г., } \\
\text { Курган № } 23 \text { погребение № } 3\end{array}$ & XY (мужской) & HV0a & - \\
\hline $\begin{array}{l}\text { Казбуруновский I курганный могильник, } 2014 \text { г., } \\
\text { Курган № 23, погребение № } 4 \text { (левое) }\end{array}$ & XX (женский) & $\mathrm{U} 2 \mathrm{e} 2 \mathrm{a} 1 \mathrm{a} 2$ & R1a1a1 \\
\hline $\begin{array}{l}\text { Казбуруновский I курганный могильник, } 2014 \text { г., } \\
\text { Курган № 23, погребение № } 4 \text { (правое) }\end{array}$ & XY (мужской) & U5a1 & R1a1a1 \\
\hline $\begin{array}{l}\text { Казбуруновский I курганный могильник, } 2014 \text { г., } \\
\text { Курган № 23, погребение № } 5\end{array}$ & XY (мужской) & HV0a & R1a1a1 \\
\hline $\begin{array}{l}\text { Казбуруновский I курганный могильник, } 2014 \text { г., } \\
\text { Курган № 23, погребение № } 6\end{array}$ & XX (женский) & U4b1a1a1 & - \\
\hline
\end{tabular}

В кургане № 5 Казбуруновского I курганного могильника было выявлено два погребения. В центре кургана было обнаружено погребение взрослого мужчины 50-59 лет. Костяк был ориентирован по линии север - юг, на левом боку. В вертикальной проекции, кости черепа располагались на 0,25 м выше, чем длинные кости ног. Перечисленное может свидетельствовать о том, что погребенный лежал на 
настиле с поднятым изголовьем. Палеоантропологический анализ выявил наличие системного заболевания опорно-двигательного аппарата - позвоночный столб погребенного полностью сросся. Подобные следы заболевания были отмечены также на тазовых и бедренных костях, что может свидетельствовать о заболевании погребенного коксартрозом. Выявленное системное заболевание погребенного, скорее всего, привело к невозможности этого человека стоять, а возможно, даже и сидеть. Кроме того, была установлена и возможная причина смерти погребенного - это перелом основания черепа.

В этом же кургане, в погребении № 2, было выявлено захоронение подростка женского пола возраста 14 лет. При палеоантропологическом анализе были выявлены «маркеры стресса» на зубах погребенного, что говорит о неравномерности питания в различные периоды развития подростка.

В 2009 г. в кургане № 16 было также выявлено два погребения. Одно из них принадлежало ребенку (женский пол) возраста 8-9 лет, от которого сохранились только фрагменты костей свода черепа, несколько ребер и небольшой фрагмент верхней челюсти. Центральное погребение (мужской пол погребенного) (погребение № 1) было совершено в каменной (кальцитовой) цисте, что является экстраординарным способом погребения для Центральной Башкирии. Погребенный находился на левом боку, по линии север - юг. Несмотря на плохую сохранность костей скелета, палеоантропологический анализ указал на наличие тех же системных заболеваний опорно-двигательного аппарата, что и в вышеуказанном погребении.

В кургане № 23 было выявлено семь погребений, что само по себе является неординарной ситуацией для курганных захоронений срубной и алакульской культур правобережной части реки Уршак, в курганах которых, как правило, встречается одно или два погребения. В погребении № 4 было выявлено парное захоронение мужчины и женщины, расположенных лицами друг к другу. Женщина, лежавшая в левой части могильной ямы, была 25-28-летнего возраста. Мужчине, лежавшему справа, было 30-35 лет. У него была сломана правая большеберцовая кость. Перелом был крученым и диагональным, несмотря на сложность травмы, большеберцовая кость полностью срослась, хотя и со значительным смещением. Наложение сломанных частей кости друг на друга составило 5 см. При реконструкции погребального комплекса было обнаружено, что первым захоронением в нем было женское, вторым, по хронологии формирования парного погребения, - мужское. Предположительно, мужчина был позднее положен к телу женщины, о чем свидетельствует положение мужского костяка. Женщина является «композиционным центром» этого погребения, ее костяк положен в «классической позе», что не относится к атипичному по положению мужскому скелету.

Как уже отмечалось, наиболее презентативными при исследовании погребений стали палеоантропологические анализы, позволившие дать остеобиографические описание погребенных. Эти анализы дали следующие результаты: определен пол погребенных в памятниках позднего бронзового века Казбуруновского археологического микрорайона -7 мужчин и 7 женщин. Установлены причины смерти - убийства (возможные) - 2, возраст - 2 ребенка (9 мес. - 1,5 года), 9 погребенных - возраст 50-59 лет, 1 погребенный - 40-45 лет. Также было установлено наличие у всех взрослых системных заболеваний опорно-двигательного аппарата, а также отит у ребенка (9 месяцев - 1 год). Для двух из выявленных четырех погребений Казбуруновского микрорайона было характерно наличие «маркеров стресса», зафиксированных на зубах инфантов. Таким образом, исходя из вышесказанного, мы можем заключить, что первоначальные результаты показали недостаточное количество погребений лиц среднего возраста. Данный факт также может быть определен как «экстраординарность».

В отечественной археологии эпохи позднего бронзового века одной из исследуемых проблем является степень скорченности погребенных.

Данный вопрос рассматривался в нескольких публикациях $[13 ; 14$, с. $34-69 ; 15$, с. 136-194; 16, с. 5-17; $17 ; 18$, с. $88-111 ; 19$, с. $102-104 ; 20]$. Как правило, авторы связывали скорченность костяков с различными обрядовыми группами. На наш взгляд, представляется возможным говорить о различиях в скорченности, связанной, прежде всего, с гендерными различиями погребенных.

И.С. Каменецкий и В.А. Кореняко, прежде чем начать рассмотрение углов скорченности, пытаются ответить на вопрос о влиянии посмертного положения тела на углы скорченности. В действительности, на сегодняшний день мы не можем утверждать, что положение скелета, которое мы фиксируем при расчистке погребений, было таковым на момент помещения тела в могильную яму. На положение костяка в могиле могли влиять как объективные, так и субъективные причины $[15$, с. 149]. Исходя из этого положения, И.С. Каменецкий считает, что примененный В.А. Кореняко метод замера углов скорченности каждой из ног [16, с. 5-17], излишним [15, с. 139]. По мнению И.С. Каменецкого, отличие на $5^{\circ}$ угла сгиба ног в коленном суставе не является определяющим.

И.А. Сорокина, ссылаясь на И.С. Каменецкого, выделяет два основных критерия для определения степени скорченности - это критерий «А» (скорченность в тазобедренном суставе) и критерий «Б»скорченность в коленном суставе. Описывая критерий «А», автор указывает лишь градусную меру угла в $45-50^{\circ}, 70^{\circ}$ и $90^{\circ}$, что, вероятно, должно соотноситься с сильной, средней и слабой степенью скорченности соответственно. По критерию «Б» И.А. Сорокина рассматривает углы в $10^{\circ}$ и $20^{\circ}$, что, по ее мнению, соответствует сильной и средней степени скорченности [14, с. 34-69].

В работе Ю.И. Колева ставится вопрос о соотношении градусной меры сгибов с определением «сильной», «средней» и «слабой» скорченности [18, с. 105]. Автор, следуя исследованию В.А. Кореняко, предполагает, что сильная степень скорченности может объясняться связыванием.

В кандидатской диссертации Ю.В. Луньковой материал по скорченности систематизирован в таблицу. Исходя из данных таблицы, слабая степень скорченности между бедренной костью и позвоночником менее $60^{\circ}$; угол сгиба в коленях - менее $40^{\circ}$. Средняя степень скорченности между бедренной костью и позвоночником $-60-100^{\circ}$; угол сгиба в коленях более $40^{\circ}$. Максимальная степень скорченности 
между бедренной костью и позвоночником - более $100^{\circ}$; угол сгиба в коленях - более $40^{\circ}$. В данном случае мы видим, что критерий «Б» выглядит достаточно «размытым», так как в обоих случаях представлен показатель градусной меры угла «более $40^{\circ} »$, без уточнения [17, табл. 2, с. 195].

В.В. Ткачев связывает степень скорченности с обрядовыми группами погребений [19, с. 102-103], выделяя две из шести групп.

Рассмотрение проблемы скорченности погребенных было проведено и в монографии М.В. Андреевой, однако эта работа была посвящена катакомбной культуре. Мы можем принимать во внимание информацию, нашедшую отражение в этом исследование, в качестве аналогии. Автор указывает, что средняя скорченность ног в тазобедренном суставе составляет $90^{\circ}$; сильная или максимальная степень скорченности в коленном суставе $-45^{\circ}$ [20, с. 24]. Слабую скорченность («слабоскорченность») М.В. Андреева связывает с естественным сгибом в коленях [20, c. 78].

Нами была сделана попытка применения этих данных на примере курганных захоронений Казбуруновского I курганного могильника Казбуруновского археологического микрорайона. Считаем необходимым отметить, что вышеназванные исследователи не принимали в расчет такой показатель, как угол локтевого сгиба. Мы предлагаем назвать его критерием «В» и определить, по аналогии, угловую размерность в $20^{\circ}$ как сильную, промежуток $37^{\circ}-40^{\circ}$ как среднюю и $55^{\circ}$ - как слабую скорченность.

Рассматривая погребение 1 кургана № 5, необходимо отметить, что костяк взрослого мужчины находился в крупной и достаточно глубокой могильной яме с серьезным нарушением анатомического положения костяка. Такое положение могло быть связано как с воздействием грызунов, так и с вероятной конструкцией, на которую был помещен погребенный, с более высоким положением верхней части тела по сравнению с нижней. Вместе с тем нижняя часть костяка погребенного оказалась практически нетронутой грызунами и располагалась в анатомическом порядке. Так как погребенный располагался на какихто носилках, то при расположении тела скорчено на левом боку, произошло «сползание» тела с небольшим разворотом, что привело к «разведению» ног. Угол сгиба в коленном суставе правой ноги составил $15^{\circ}$, а в коленном суставе левой ноги $-40^{\circ}$. Угол, составленный фрагментами сохранившегося позвоночного столба и бедренными костями, имел градусную меру в $85^{\circ}$, что близко к прямому углу. Таким образом, мы можем сказать, что, исходя из измерений и усреднения градусных мер углов коленных сгибов, мы получаем цифру в $27,5^{\circ}$, что указывает на среднюю степень скорченности по критерию «Б», а угол скорченности по критерию «А» свидетельствует о промежуточном положении - между средней и слабой степенью скорченности.

Погребение 1 кургана № 16 также в силу различных причин сохранилось неудовлетворительно. У костяка не сохранились тазовые кости, позвоночный столб и практически все ребра. Если предположить, что длинные кости ног располагались в расчищенном погребении в анатомическом порядке, то они были очень сильно подогнуты к остаткам грудной клетки. Угол коленного сгиба правой ноги составлял $17^{\circ}$, а левой ноги $-23^{\circ}$. Сохранившиеся длинные кости рук, также прижатые к грудной клетке, показали угол сгиба в локте в $55^{\circ}$. Исходя из обозначенных критериев, мы можем утверждать, что ноги находились в средней степени скорченности, а руки в слабой степени скорченности.

В погребении 5 кургана № 23 обнаружен костяк очень хорошей сохранности, расположенный в анатомическом порядке, за исключением некоторой «отклоненности» левой части костей большого таза, а также сдвинутого к западу от костей таза крестца. Ноги погребенного были сильно прижаты как к тазовым костям, так и к грудной клетке, что могло свидетельствовать о возможном связывании тела. Угол сгиба левой ноги в коленном суставе составлял $16^{\circ}$. Угол между тазовыми и бедренными костями составлял $13^{\circ}$. Угол между тазовыми костями и позвоночным столбом составлял $80^{\circ}$. Длинные кости рук были вплотную прижаты к грудной клетке, не позволяя вычислить угол сгиба. По критерию «А» у костяка отмечается состояние скорченности между средней и слабой степенью; по критерию «Б»- средней степени.

Правое погребение из могилы 4 кургана № 23 является экстраординарным. Костяк мужчины был «вторичным» при погребении женщины. Он был помещен в могилу сверху женского костяка, с небольшим разворотом нижней части тела и грудной клетки. Угол сгиба в коленях составил $35^{\circ}$ (слабая степень скорченности), угол между тазовыми костями и позвоночным столбом составил $82^{\circ}$ (промежуточное между средней и слабой степенью скорченности).

Погребение 2 кургана № 5 было представлено костяком девочки-подростка хорошей сохранности, расположенном в анатомическом порядке. Угол сгиба в коленях составлял $26^{\circ}$, угол между тазовыми костями и позвоночным столбом составил $85^{\circ}$, а угол сгиба в локтевом суставе составил $42^{\circ}$. По критерию «А» мы можем говорить о слабой скорченности, по критерию «Б»- о средней степени, а по критерию «В»- также о средней степени скорченности.

Погребение 2 кургана № 23, тоже представленное костяком девочки-подростка, продемонстрировало неплохую сохранность скелета, расположенного в анатомическом порядке. В связи с горизонтальным разворотом костей большого таза длинные кости ног несколько сдвинулись относительно друг друга. Угол коленного сгиба правой ноги составил $36^{\circ}$, а угол сгиба левой ноги составил $31^{\circ}$. Так как таз оказался развернут в плоскости, то угол, замеренный между бедренными костями и позвоночным столбом, составил $92^{\circ}$. Длинные кости рук погребенной были плотно прижаты к грудной клетке, что привело к тому, что пястья и пальцы рук оказались под подбородком и нижней челюстью. Угол сгиба в локтевом суставе составил $23^{\circ}$. Критерий «А» показал слабую степень скорченности, критерий «Б» - также продемонстрировал слабую степень скорченности, а критерий «В» показал сильную степень скорченности.

Погребение 6 кургана № 23, принадлежавшее женщине средних лет, продемонстрировало хорошую сохранность костяка с правильным анатомическим положением. Угол сгиба в коленном суставе правой ноги составлял $40^{\circ}$, а в коленном суставе левой ноги $-35^{\circ}$. В связи с разворотом тазовых костей в плоскости, измерялся угол между бедренными ко- 
стями и позвоночным столбом, который составил $85^{\circ}$. Длинные кости рук были несколько отодвинуты от грудной клетки в районе локтевых сгибов, что привело к нахождению пястий и пальцев перед лицом погребенной. Угол сгиба длинных костей рук в локтях составил $35^{\circ}$. Исходя из обозначенных критериев, можно сделать вывод, что критерий «А» говорит о слабой степени скорченности, критерий «Б» также говорит о слабой скорченности, а критерий «В» о средней степени.

Левое погребение могилы 4 кургана № 23 было представлено хорошо сохранившимся женским костяком средних лет, находившимся в анатомическом положении. Берцовые кости ног были подогнуты к тазовым костям, угол между длинными костями ног в коленных сгибах составил $25^{\circ}$. Угол сгиба между тазовыми костями и позвоночным столбом составил $87^{\circ}$. Руки были выдвинуты в сторону от грудины в локтях, что привело к расположению кистей и пальцев под нижней челюстью. Угол сгиба в локтях составил $37^{\circ}$. Критерий «А» говорит о слабой степени скорченности, критерий «Б» также говорит о слабой скорченности, а критерий «В» о средней степени.

Современные социальные реконструкции, включающие некоторые аспекты гендерных ролей в дописьменных обществах, невозможны без интердисциплинарного подхода, с опорой на анализы биоархеологии, с учетом исторического контекста позднего бронзового века Южного Приуралья. Проведенное на территории Казбуруновского археологического микрорайона исследование показало, что в отдельных случаях в погребальной практике имеются прорывные свидетельства наличия идентичности и жизненного опыта не только акторов погребального обряда, но и самих погребенных, о чем свидетельствует парное погребение мужчины и женщины.

Индивидуализированно выступает остеобиографии мужчин: одного, получившего прижизненный тяжелый перелом ноги, и второго, у которого с возрастом сформировались внегендерные системные заболевания опорно-двигательного аппарата, которые привели к сращению позвонков. Подобные данные не что иное, как свидетельства индивидуальной жизни, помогающие восстановить исторический контекст в виде сплоченной общины, содержавшей родственника (соплеменника) длительное время.

Сложность экологического ландшафта и сплоченность общины, с одной стороны, нивелировали системные заболевания по гендерному признаку, с другой стороны, создавали основу поддержки и лечения взрослых соплеменников - мужчин, что нашло отражение в возрастном составе захоронений, в которых превалировали дети и мужчины старшего поколения при отсутствии индивидов - мужчин среднего возраста.

Таким образом, по результатам комплексного применения остеобиографического метода, палеогенетического анализа и анализа степени скорченности мы можем утверждать, что мужские захоронения имели по используемым критериям сильную и среднюю степень скорченности, в то время как женские тяготели к средней и слабой степени скорченности. B настоящее время, используя методы aDNA, мы можем исключить как отдельную «детскую» группу захоронений (по степени скорченности), учитывая ее данные в двух крупных гендерных группах мужчин Самарский научный вестник. 2018. Т. 7, № 3 (24) и женщин, в случае отсутствия «специального» детского инвентаря.

Данные остеобиографического анализа говорят об особых гендерных ролях в древних обществах на примере погребенных на территории Казбуруновского археологического микрорайона мы можем утверждать наличие травм костного скелета только у мужчин. Наличие сложных травм костного скелета у мужчин может свидетельствовать не только о важной социальной роли мужчин, но и о высокой социальной организации древних групп населения срубной и алакульской культурных общностей, которая позволяла людям с такими опасными повреждениями не только выжить, но и вернуться к «полноценному» исполнению своих гендерных ролей. Также, исходя из анализа степени скорченности детских захоронений, можно сделать вывод о том, что гендерные роли были определены в древнем обществе с момента рождения человека.

\section{Список литературы:}

1. Moutafi I. The cremation burial and other human remains, in The Settlement at Dhaskalio // The cremation burial and other human remains, Publisher: McDonald Institute for Archaeological Research / Eds.: C. Renfrew, O. Philaniotou, N. Brodie, G. Gavalas, M.J. Boyd. Cambridge: McDonald Institute for Archaeological Research, 2013. P. 451-462.

2. Moutafi I., Voutsaki S. Commingled Burials and Shifting Notions of the Self at the onset of the Mycenaean Era (1700-1500 BC): The Case of the Ayios Vasilios North Cemetery, Laconia // Journal of Archaeological Science. 2016. Reports 10. P. 780-790.

3. Knüsel C. Bioarchaeology: A Synthetic Approach // Bulletins et mémoires de la Société d'anthropologie de Paris. 2010. № 22. P. 62-73. DOI: 10.1007/s13219-0100003-1.

4. Saul F., Saul J.M. Osteobiography: a Maya example // Reconstruction of Life from the Skeleton / Ed. by M. Iscan, K.A.R. Kennedy. New York: Alan R. Liss, 1989. P. 287-302.

5. Boutin A.T. Crafting a bioarchaeology of personhood: osteobiographical narratives from Alalakh // Breathing New Life into the Evidence of Death: Contemporary Approaches to Bioarchaeology. - School for Advanced Research Press, 2011. P. 109-133.

6. Щербаков Н.Б., Шутелева И.А., Гольева А.А., Луньков В.Ю., Лунькова Ю.В., Орловская Л.Б., Леонова Т.А., Горшков К.А. Казбуруновский археологический микрорайон позднего бронзового века Южного Приуралья: результаты естественнонаучных исследований. Уфа, 2017. 164 с.

7. Щербаков Н.Б., Шутелева И.А., Гольева А.А., Леонова Т.А. Модели степной технологической и миграционной мобильности позднего бронзового века Башкирского Приуралья // V (XXI) всерос. археологический съезд. Барнаул, 2017. С. 1193-1194.

8. Shcherbakov N., Shuteleva I., Leonova T., Golyeva A. The experience of comparative radiocarbon dating of Late Bronze Age Southern Cis-Urals // Second Radiocarbon in the Environment Conference. Debrecen, 2017. P. 67-68.

9. Golyeva A., Khohlova O., Shcherbakov N., Shuteleva I. Negative effects of Late Bronze Age human activity on modern soils and landscapes, a case-study on the 
Muradymovo Settlement, Urals, Russia // Interdisciplinaria archaeologica: natural sciences in archaeology. 2016. Vol. VII, Is. 2. P. 29-36.

10. Шутелева И.А., Щербаков Н.Б., Гольева А.А., Луньков В.Ю., Лунькова Ю.В., Леонова Т.А., Орловская Л.Б., Радивоевич М. Результаты интердисциплинарных исследований памятников срубно-алакульского типа Башкирского Приуралья (на примере Казбуруновского археологического микрорайона) // Краткие сообщения Института археологии (КСИА). Вып. 246. М., 2017. С. 261-279.

11. Щербаков Н.Б., Шутелева И.А., Горшков К.А. Проблемы палеодемографической мобильности населения эпохи позднего бронзового века Башкирского Приуралья на примере материалов Казбуруновского археологического микрорайона Южного Приуралья // Миссии антропологии и этнологии: научные традиции и современные вызовы. ХІІ Конгресс антропологов и этнологов России. Ижевск, 2017. С. 143.

12. Sherbakov N., Shuteleva I., Obydennova G., Balonova M., Khohlova O., Golyeva A. Some Results of the Application of a Complex Approach to the Research of the Late Bronze Age Muradymovo Settlement in the Volgo-Ural Region // Interdisciplinaria Archaeologica Natural Sciences in Archaeology. 2010. Vol. I. Is. 1-2. P. 29-36.

13. Бунятян Е.П. Методика социальных реконструкций в археологии. На материале скифских могильников IV-III вв. до н.э. Киев, 1985. 228 с.
14. Сорокина И.А. Погребения эпохи поздней бронзы в Западном Предкавказье (к методике исследования) // Археологические открытия на новостройках. Древности Северного Кавказа: материалы работы Северокавказской экспедиции. Вып. 1. М.: Наука, 1986. С. 34-69.

15. Каменецкий И.С. Код для описания погребального обряда (часть вторая) // Археологические открытия на новостройках. Древности Северного Кавказа: материалы работы Северокавказской экспедиции. Вып. 1. М.: Наука, 1986. С. 136-194.

16. Кореняко В.А. К методике изучения погребений со скорченными скелетами // Советская археология. 1984. № 3. С. 5-17.

17. Лунькова Ю.В. Погребальный обряд срубной культуры Волго-Донского междуречья: дис. ... канд. ист. наук. М., 2002. 245 с.

18. Колев Ю.И. Грунтовый могильник срубной культуры Съезжее II (материалы раскопок) // Материальная культура населения бассейна реки Самары в бронзовом веке. Самара, 2003. С. 88-111.

19. Ткачев В.В. Степи Южного Приуралья и Западного Казахстана на рубеже эпох средней и поздней бронзы. Актобе, 2007. С. 102-104.

20. Андреева М.В. Восточноманычская катакомбная культура. Анализ материалов погребальных памятников. М., 2014. 272 с.

Статья публикуется при поддержке госзадания по ГП 0148-2016-0003.

\section{NEW APPROACHES TO MODELS OF GENDER ROLES OF THE LATE BRONZE AGE OF THE SOUTHERN URALS: KAZBURUN ARCHEOLOGICAL MICRODISTRICT (ON THE EXAMPLE OF THE RESULTS OF A BIOARCHEOLOGICAL ANALYSIS)}

Shcherbakov Nikolai Borisovich, candidate of historical sciences, researcher of Methodology and Methods of Humanitarian Studies Laboratory Shuteleva Iia Alexandrovna, candidate of historical sciences, researcher of Methodology and Methods of Humanitarian Studies Laboratory

Leonova Tatiana Alekseevna, candidate of historical sciences, head of Methodology and Methods of Humanitarian Studies Laboratory Bashkir State Pedagogical University named after M. Akmulla (Ufa, Russian Federation) Gorshkov Konstantin Alexandrovich, forensic expert of Medical-Forensic Department Bureau of Forensic Medical Examination (Ufa, Russian Federation) Golyeva Alexandra Amurievna, doctor of geographical sciences, leading researcher of Geography and Evolution of Soils Department Institute of Geography of Russian Academy of Sciences (Moscow, Russian Federation) Baturina Alexandra Nikolaevna, student of History and Public Administration Institute Bashkir State University (Ufa, Russian Federation)

Abstract. Complex archaeological studies carried out on the monuments of the developed classical Late Bronze Age in the territory of the Southern Urals, Kazburun archeological microdistrict allowed to apply the method of osteobiography to the reconstruction of gender features of the funeral rite. The received radiocarbon dates allowed not only to overstate the history of the inhabitants of the Srubnaya and Alakul cultural tastes for a period of 350-400 years in this territory, but also to show the finding of all those buried in the same chronological horizon. At the same time, a comparative radiocarbon analysis of the materials of funerary and settlement complexes also showed their simultaneity. DNA data made it possible to distinguish the specificity of the funeral rite. A strong degree of crookedness as a gender characteristic of the buried Scorpion is suggested to be investigated both in the «traditional» description (crookedness in the hip joint and crookedness in the knee joint, and use the parameter of scorpionctomy in the elbow joint of the buried). Anthropological analyzes characterized a number of paleoblocks as a gender attribute for the homogeneous paleodiet of the ancient population of the Kazburun archaeological microdistrict. Soil research methods have made it possible to determine the nature of the interaction of the ancient population and the modern paleo-environment, thus revealing the level of ancient anthropogenic impact on the environment, to identify probable traditions in the construction of the ancient population.

Keywords: developed classical late bronze age of Southern Urals; Srubnaya and Alakul archaeological communities; osteobiography; isotopic analyzes ( $113 \mathrm{C}$ and $\mathrm{d} 15 \mathrm{~N})$ for reconstruction of paleodieta and establishment of radiocarbon chronological scale; paleogenetic analysis; soil analysis; paleoanthropological analisys. 